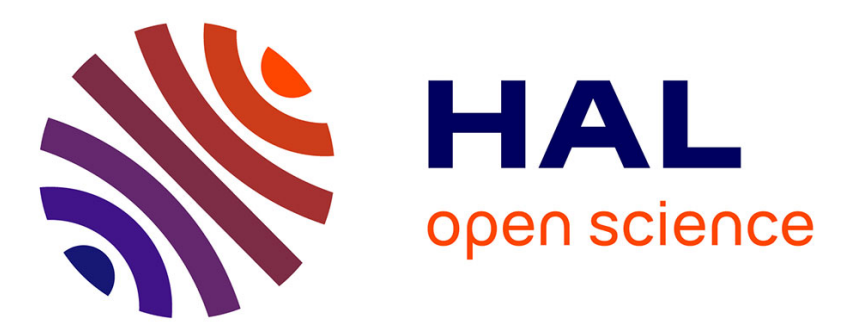

\title{
Smartphone use during shopping and store loyalty: The role of social influence
}

Isabelle Collin-Lachaud, Mbaye Fall Diallo

\section{To cite this version:}

Isabelle Collin-Lachaud, Mbaye Fall Diallo. Smartphone use during shopping and store loyalty: The role of social influence. International Journal of Retailing \& Distribution Management, 2021, 10.1108/IJRDM-03-2020-0109 . hal-03156195

\section{HAL Id: hal-03156195 \\ https://hal.science/hal-03156195}

Submitted on 2 Mar 2021

HAL is a multi-disciplinary open access archive for the deposit and dissemination of scientific research documents, whether they are published or not. The documents may come from teaching and research institutions in France or abroad, or from public or private research centers.
L'archive ouverte pluridisciplinaire HAL, est destinée au dépôt et à la diffusion de documents scientifiques de niveau recherche, publiés ou non, émanant des établissements d'enseignement et de recherche français ou étrangers, des laboratoires publics ou privés. 
Pour le citer : COLLIN-LACHAUD I. et DIALLO M.F. (2021) Smartphone use during shopping and store loyalty: The role of social influence, International Journal of Retail \& Distribution

Management, en ligne depuis le 12 Janvier

\title{
Smartphone use during shopping and store loyalty: The role of social influence
}

\begin{abstract}
:
Purpose - Smartphone use within stores is increasingly popular among customers. This research seeks to investigate how in-store mobile use affects store loyalty directly or indirectly via the mediation of store value and whether social influence moderates such relationships.
\end{abstract}

Design/ Methodology - Based on a sample of 862 actual customers from a market research company panel, we used structural equation modeling to test a series of research hypotheses. Findings - The results show a positive but weak effect of in-store smartphone use on loyalty. This effect is significantly mediated by the store's hedonic and symbolic value dimensions, but not by its utilitarian value. This research also uncovers significant moderation effects of social influence on the relationships investigated. The effect of in-store smartphone use on store loyalty is stronger when social influence is lower. However, the effects of hedonic and symbolic store value are stronger when social influence is higher.

Research limitations - This research is carried out in one country (France). It focuses on social influence through in-store mobile phone use; it would also be useful to consider physical social influence.

Practical implications - Retailers should position their stores on specific value dimensions and use social influence appropriately to improve loyalty. For instance, utilitarian value should be offered to customers with low social influence. To prevent negative social 
influence, retailers could develop "controlled" social influence through their own private mobile app to favor interaction.

Originality/value - This research underlines the critical role of store value and social influence on the relationships between in-store smartphone use and store loyalty. It shows that the effects of value dimensions (utilitarian, hedonic and symbolic) on loyalty differ depending on social influence level.

Keywords: in-store smartphone use, mobile, store loyalty, store value, social influence.

Paper type: Research paper 


\section{Smartphone use during shopping and store loyalty: The role of social influence}

\section{Introduction}

"No recent technological innovation has had a more transformative effect on consumers' lives than the virtually indispensable smartphone" (Melumad and Pham, 2020, p. 237). Indeed, among all the technological innovations that have fundamentally altered how consumers shop (Daunt and Harris, 2017; Grewal et al., 2020; Inman and Nikolova, 2017), the smartphone ${ }^{1}$ plays a crucial and specific role (Bellini and Aiolfi, 2017, 2020; de Kerviler et al., 2016b; Rippé et al., 2017; Verhoef et al.; 2017). Consumers are constantly connected due to their increasing smartphone usage and specifically when they shop in store (Bellini et al., 2018; de Haan et al., 2018; Grewal et al., 2018). According to Bellini and Aiolfi (2020, p. 1), "Widespread "anywhere and anytime" connectivity breaks the historical sequence of the decision-making process by allowing consumers to consult the network not only out-of-store, but also in-store when they are close to making a purchase decision". In-store smartphone use means that consumers are not only influenced by people (retail personnel, other known or unknown consumers) or information in store, but also by those not in the store (family, friends, social media, etc.). Although there has long been interest in the important impact of social influence on consumers in the retail environment (Argo et al., 2005), the digital transformation of retailing (including the increasing in-store use of mobiles) extends the effect of social influence on consumers' attitudes and behaviors and, consequently, requires further research as suggested recently by Argo and Dahl (2020).

According to the BRP consumer survey "2019 Special report: In-store mobility"”, while in store, $63 \%$ of consumers rely on their smartphone whether to compare prices $(34 \%)$, search

\footnotetext{
${ }^{1}$ In this paper, mobile means a smartphone that offers numerous functions such as a camera, Internet access, multimedia players, mobile application downloads (for banking, shopping, travelling, working, etc.), and so on. Mobile and smartphone are used as synonymous in this paper.

${ }^{2}$ https://brpconsulting.com/download/2019-special-report-in-store-mobility/.
} 
for coupons or special deals/offers $(28 \%)$, check local inventory/product availability (18\%) or look for product information (16\%). Retailers have clearly understood how important it is to provide their customers with an in-store mobile experience, with $49 \%$ considering it one of their top customer engagement priorities.

These statistics concern the US market but are fully consistent with those on other markets such as France, where this research was conducted. Indeed, in-store mobile use is on an upward trend in France, with various motivations including comparing prices, consulting customer reviews or checking product characteristics $(38 \%)$, receiving geolocalized promotional deals $(24 \%)$ and paying $(12 \%) .{ }^{1}$ Thus, the ability to easily use smartphones in store could influence customers' store choice or purchase behaviour within the store (Bellini and Aiolfi, 2017, 2020; de Kerviler et al., 2016b). However, it is not clear how such a relationship relates to value derived from the store, or whether social influence through instore mobile phone interactions strengthen or weaken it.

The rapid growth of smartphone market penetration (Grewal et al., 2018) and the increasing ease-of-use of mobile devices enable consumers to take control of their omnichannel shopping experience (de Haan et al., 2018; Lemon and Verhoef, 2016; Siregar and Kent, 2019). Although research about mobiles has increased in recent years, practitioners still have little guidance about the strategy they should adopt concerning in-store smartphone use (Bellini and Aiolfi, 2017). Indeed, most of the existing research on the role of mobiles in consumer behaviour has focused on mobile advertising and promotions (Grewal et al., 2016), mobile shopping (van Heerde et al., 2019) or mobile payment (Falk et al., 2016). Relatively few studies are dedicated to in-store mobile use (Bellini and Aiolfi, 2017, 2020; Grewal et al., 2018; de Kerviler et al., 2016b; Rippé et al., 2017) while it has a growing and pervasive influence on shopping behaviour (de Haan et al., 2018; Sciandra and Inman, 2015). With the increasing number of customers using their mobile phones while shopping, retail companies 
need to understand how in-store mobile use affects store value dimensions (utilitarian, hedonic and symbolic), but also how social influence (Argo and Dahl, 2020) affects the relationships between in-store mobile use, store value and store loyalty. Building and maintaining store value and store loyalty are extremely critical in an omni-channel context where the available channels for customers to shop have proliferated (Kamran-Disfani et al., 2017) and where customer "showrooming" has become a major threat to physical stores (Daunt and Harris, 2017).

The specific aim of this research is therefore to investigate how in-store mobile use affects store loyalty directly or indirectly via the mediation of store value and whether social influence moderates such relationships. As such, this paper contributes to the literature and practice in two main ways.

First, it shows that in-store smartphone use affects customer loyalty directly but also indirectly through store value perceptions. Specifically, we complement the existing research on the impact of in-store mobile phone use (e.g. Bellini and Aiolfi, 2017, 2020; Grewal et al., 2018; Rippé et al., 2017) by clarifying the role of different value dimensions (utilitarian, hedonic and symbolic) on the relationships between in-store smartphone use and customer loyalty in a context of omni-channel retailing. Consequently, this research indicates to retail managers how to position stores on specific value dimensions to improve loyalty.

Second, it establishes a significant moderation role of social influence in the relationships between smartphone use, store value and store loyalty. It specifically underscores the different roles of social influence depending on whether smartphone use or store value is an antecedent of loyalty. We also show structural differences between utilitarian and non-utilitarian value in relation to the moderation process of social influence. Thus, we provide specific guidance to retail companies as to how they should monitor and use social 
influence appropriately and consequently increase loyalty and mitigate showrooming behaviour.

The rest of the article is structured as follows. The next section presents the theoretical framework and related hypotheses. Next, the research methodology is outlined, followed by the results. Finally, the theoretical/managerial implications and limitations are discussed.

\section{Literature review and conceptual model}

\section{Theoretical framework:}

When they shop in store, consumers rarely operate in isolation (Argo and Dahl, 2020), particularly since the rise of in-store mobile use. Thus, the overarching theory into which this research fits is that of social influence (Kelman, 1958), which tells us that an individual's attitudes, beliefs and subsequent actions or behaviors are influenced by referent others. We therefore posit that social influence affects the relationships between in-store mobile phone use, store value and store loyalty. As this research is the first to analyze the effect of social influence on these constructs, it is exploratory in nature.

\section{Social influence}

In the specific context of retailing, social influence refers to "the myriad ways that a secondary actor or actors (e.g., retail staff, other customers) can impact a focal customer's thoughts, feelings, and behaviours during a retail shopping experience" (Argo and Dahl, 2020, p. 25). As consumers can be influenced in different ways by peers patronising the store at the same time (Argo et al., 2005; Chebat et al., 2014; Zhang et al., 2014), they can imitate others using their smartphone as reported in other sectors (Kirova and Vo Thanh, 2019). De Kerviler et al. (2016a, 2016b) demonstrated that consumers use their mobile to strengthen their social identity when they are surrounded by other customers in the store. By using their mobile in- 
store, customers can also be influenced by other consumers' opinions or knowledge outside the store. Social influence can indeed originate from unknown consumers through exposure to online consumer reviews or comparative price apps (Verhoef et al., 2017) or from known consumers, for instance by asking family members and/or friends for their opinion by phone or text message while shopping (Sciandra and Inman, 2015).

\section{Customers' in-store smartphone use}

Customers now intensively use their mobile phone while shopping, which changes their behaviour and impacts retailers and their sales personnel (Bellini et al., 2018; Grewal et al., 2018; Rippé et al., 2017). Different usages of mobile phones are reported such as a guide for purchases (Bellini et al., 2018). Specifically, customers who use their mobile in store in a shopping-related manner (price comparisons, store mobile apps, etc.) buy fewer unplanned items and shop in a more accurate way which is not the case of consumers who are distracted by their mobile use in a manner unrelated to the task of shopping (e.g. personal phone calls, answering emails or text messages, etc.) (Bellini et al., 2018; Bellini and Aiolfi, 2020; Sciandra and Inman, 2015). Distraction due to in-store mobile use can have both positive (Grewal et al., 2018) and negative effects on sales according to contingency factors (Bellini and Aiolfi, 2017; Bellini et al., 2018; Sciandra and Inman, 2015). Grewal et al. (2018) showed that in-store mobile use does not lower consumer satisfaction with their shopping experience. However, although recent research has provided some insights into the effect of in-store mobile use on store purchases, it does not investigate its impact on important variables for retailers (e.g., store loyalty, store value), or whether social influence can affect the relationships between these constructs. 


\section{Store loyalty}

Customer loyalty is a crucial issue for managers. Despite numerous studies, retailers still need more guidance to better understand store loyalty-building mechanisms (Francioni et al., 2018; Kamran-Disfani et al., 2017; Rokonuzzaman et al., 2020). Store loyalty is a non-random "behavioural response (i.e., revisit or recommendation), expressed over time, by some decision-making unit with respect to one store out of a set of stores, which is a function of psychological processes resulting in brand commitment" (Bloemer and de Ruyter, 1998, p. 500). This definition highlights the concomitance of a psychological bond to the seller and of behavioural loyalty (e.g., observed repeat purchase behaviour or recommendation). As in most studies, store loyalty is reflected herein both by attitudinal commitment and re-visit intention (Diallo et al., 2015; Yoo and Donthu, 2001; Zhang and Peterson, 2004). Prior research have studied a number of determinants of loyalty in an omni-channel retail context (Singh, 2019). Among the main antecedents of store loyalty, several researchers underline the importance of value (Diallo et al., 2015; Graciola et al., 2020; Konuk, 2018).

Store value: a multi-dimensional approach

Shopping value represents the overall benefits derived from a shopping experience and captures consumer responses to a set of retail store attributes (Jackson et al., 2011). It comprises shopping trip value and in-store shopping value (Davis and Hodges, 2012). Shopping trip value is related to the fulfillment of consumers' general shopping motivations, whereas in-store shopping value stems from retail elements that create the shopping experiences consumers have in specific retail contexts, offering them particular benefits. This research focuses on in-store shopping value because it investigates in-store smartphone use. Many prior studies showed that retail stores can provide both hedonic and utilitarian values (Babin et al., 1994) during the shopping experience (Ipek et al., 2016). According to the 
conspicuous dimension of in-store mobile use and the social image it projects (smart shopping, high technological sophistication) (de Kerviler et al., 2016b), we also include symbolic value in this study. Thus, to fully capture the complexity of store value, a multidimensional approach is appropriate (Kim et al., 2014), comprising utilitarian, hedonic and symbolic dimensions. In an omni channel retail context, value can be increased by adding new/ smart technologies within the store. For instance, self-scanning and self-checkouts are self-service technologies (SST) that provide new services for clients (Audrin, 2020), as does in-store mobile use.

\section{Hypothesis development}

\section{Customers' in-store smartphone use and store loyalty}

Previous studies demonstrated a positive link between technological innovations (in this case smartphone use) and consumer loyalty, in both online and offline contexts (O'Cass and Carlson, 2012). The positive performance of technological devices increases store revisit intention (Inman and Nikolova, 2017). Thus, easy in-store use of a mobile phone could positively impact store choice or purchase behaviour within the store (Bellini and Aiolfi, 2017, 2020; de Kerviler et al., 2016b), as it enables consumers to take control of their omnichannel shopping experience (de Haan et al., 2018; Lemon and Verhoef, 2016; Siregar and Kent, 2019). Kowatsch and Maass (2010) also showed that the in-store use of mobile recommendation agents (MRAs) influences product purchases and predicts consumers' usage intention and store preferences. Generally, in-store mobile phone use enables information search, which reduces information asymmetry and consequently fosters trust, thus improving loyalty and repeat patronage intentions (Kim et al., 2004; Rokonuzzaman et al., 2020). Furthermore, Zhang et al. (2014) showed that customers interacting with other shoppers in their group were more likely to touch products and make a purchase; by extension, interaction 
with others (family, friends, other consumers on social medias) via smartphone could favour store loyalty. Grewal et al. (2018) demonstrated empirically that in-store mobile use increases store purchases and does not harm consumer satisfaction with their shopping experience. Thus, as satisfaction influences store loyalty (Lombart and Louis, 2012), we assume that instore mobile use can increase store loyalty. Based on these elements, we expect in-store smartphone use to positively influence store loyalty.

H1: Customers' in-store smartphone use positively affects store loyalty.

\section{Mediation effect of store value}

Unlike most studies that consider perceived value as an aggregated evaluation, this research uses a multidimensional approach to get a richer picture.

First, smartphone use is thought to have positive effects on utilitarian, hedonic and symbolic dimensions of value (Arbore et al., 2014; Jones et al., 2006; Mimouni-Chaabane and Volle, 2010). Specifically, smartphones can be used in a utilitarian manner (more effective and efficient shopping trip, greater ease of finding products thanks to mobile location-based apps, price comparison, etc.) (Bellini and Aiolfi, 2017; McLean et al., 2018), thus increasing utilitarian value. Consumers also adopt new technologies (such as mobile phones) not just as devices to enhance performance (utilitarian value), but also as sources of fun and pleasure (Venkatesh et al., 2012). Melumad and Pham (2020) recently demonstrated that smartphone use provides haptic pleasure and feelings of psychological comfort and, if needed, actual stress relief. Thus, in-store mobile phone use can create both utilitarian and hedonic value. It can also heighten these two dimensions of value as it enables a more seamless shopping experience, which is both more effective and more pleasant (Lemon and Verhoef, 2016). In addition, as the presence of others can add to the pleasure and excitement of the shopping experience (Roggeveen et al., 2020), speaking, texting or exchanging photos with others 
through smartphone use while shopping in-store can also increase hedonic value. Finally, as Arbore et al. (2014, p.169) remind us paraphrasing Levy (1959), people adopt personal and ubiquitous technologies, such as smartphones, not only for what they do (i.e., their utilitarian and hedonic value) but also because of what they mean (i.e., their symbolic value). Thus, innovation provides positive symbolic value based on its ability to support identity-signaling goals (Arbore et al., 2014). Specifically, being more effective and benefiting from specific discounts through in-store mobile use can increase self-esteem and thus symbolic value (de Kerviler et al., 2016b).

Second, the direct, positive relationship between value and customer loyalty is well established, especially in retail contexts (Diallo et al., 2015; Graciola et al., 2020; Jones et al., 2006; Konuk, 2018). Jones et al. (2006) demonstrated the positive link between utilitarian value and store loyalty. In addition, utilitarian value is also connected to loyalty because of the feeling of task achievement when completing a shopping experience flawlessly (Ipek et al., 2016). Hence, utilitarian value is supposed to increase loyalty attitudes (Babin et al., 1994). Furthermore, hedonic value can lead to increased behavioural loyalty (Jones et al., 2006) as the store is associated with positive emotions and entertainment, and an enjoyable shopping experience is often reflected in higher spending (e.g. Papagiannidis et al., 2017). As customers express social identities when shopping, their in-store smartphone use can enable them to project an image of a smart shopper; this increased symbolic value (Arbore et al., 2014) can lead to higher loyalty (de Kerviler et al., 2016b).

Based on the above, we hypothesise as follows:

H2: In-store mobile use increases store value $(\mathbf{H 2 a})$, which in turn positively affects store loyalty (H2b). 
H2.1: In-store mobile use increases utilitarian store value (H2.1a), which in turn positively affects store loyalty $(\mathbf{H 2 . 1 b})$.

H2.2: In-store mobile use increases hedonic store value $(\mathbf{H 2 . 2 a})$, which in turn positively affects store loyalty $(\mathbf{H} 2.2 \mathbf{b})$.

H2.3: In-store mobile use increases symbolic store value (H2.3a), which in turn positively affects store loyalty $(\mathbf{H} 2.3 \mathbf{b})$.

\subsubsection{Moderation effects of social influence}

Many studies have recently highlighted the importance of social influence (Arbore et al., 2014; Argo and Dahl, 2020; $\mathrm{Hu}$ et al., 2019) and particularly this of social media on consumers' attitudes and behaviours (Ascarza et al., 2017; Giovanis et al., 2018; Grewal et al., 2018; Osei-Frimpong, 2019). In the context of retailing, social influence of all types (active and passive, of known and unknown customers) can have positive outcomes for retailers (Argo and Dahl, 2020) such as more favorable purchase attitudes (Chebat et al., 2014), purchase behaviour (Zhang et al., 2014) and purchase quantities (Grewal et al., 2018). More specifically, social influence affects both smartphone use (Arbore et al., 2014; De Kerviler et al., 2016a, 2016b) and purchase intentions (e.g. Giovanis et al., 2018; Grewal et al., 2018).

However, not all consumers are equally influenced as some attach greater importance to the behaviours and opinions of others (Arbore et al., 2014; Nunes et al., 2011). Customers with a high social influence ${ }^{3}$ level are more likely to emulate the consumption behaviour and opinions of their aspirational groups (Nunes et al., 2011). Thus, they are more likely to imitate behaviours such as smartphone use (Arbore et al., 2014; Kirova and Vo Thanh, 2019), but also loyalty or disloyalty (churn) (Haenlein, 2013; Nitzan and Libai, 2011; Purani et al., 2019) to conform with others' behaviours and opinions. Indeed, a consumer is significantly more

\footnotetext{
${ }^{3}$ In this paper, high level of social influence means that consumers are highly influenced by others.
} 
likely to defect from a provider if other individuals to whom he/she is socially connected have recently done so (Haenlein, 2013).

Shrihari and Srinivasan (2012) revealed the moderation role of other consumers' online ratings in the relationship between product experience or failure and reviewers' online product ratings. Thus, we expect social influence to play a moderation role in the relationship between in-store mobile use and store loyalty, notably through other consumers' online ratings (Shrihari and Srinivasan, 2012), but also more generally through social norms (Arbore et al., 2014). Specifically, we expect the effect of smartphone use on loyalty to be weaker when social influence is higher. When in store, consumers can be influenced both by other customers shopping at the same time (Argo et al., 2005; Argo and Dahl, 2020; Chebat et al., 2014) and by exposure to online consumer reviews or ratings (Shrihari and Srinivasan, 2012; Verhoef et al., 2017) through their in-store mobile use. In this particular case, customers will tend to rely on quick facts (online ratings, stars, etc.) and be less loyal to the store. Hence, higher social influence will lead to a lower effect of in-store mobile use on store loyalty. Following all these prior studies, we hypothesise as follows:

H3. The effect of in-store smartphone use on store loyalty is weaker when the level of social influence is higher.

Beyond its impact on in-store smartphone use and store loyalty, the level of social influence can also influence the relationship between in-store smartphone use and store value. As explained above, social influence increases the adoption of new technology and product (Van den Bulte and Lilien, 2001; Venkatesh et al., 2003). Kirova and Vo Thanh (2019) also demonstrated the influence of social environment on the intensity and type of smartphone use and its impact on leisure experiences. Thus, a high level of social influence can favour instore smartphone use. Consumers also use their smartphones to enhance their social identity when surrounded by other customers in store (Arbore et al., 2014; de Kerviler et al., 2016a, 
2016b), so we expect social influence to moderate the relationship between in-store smartphone use and store value.

The different dimensions (utilitarian, hedonic and symbolic) of store value can be impacted by the level of social influence (Arbore et al., 2014). First, consumers with a high level of social influence may use their smartphone in store to connect with other consumers (online reviews, phone call to family or friends, etc.) and obtain price comparisons to reduce the perceived risk associated with store purchasing information. Thus, a high level of social influence fosters utilitarian value and store loyalty. Jung (2014) confirms this role of high social influence by demonstrating that positive self-image, which is formed by maintaining positive social relationships through the use of smartphones, significantly leads to pleasure. Kirova and Vo Thanh (2019) also demonstrated the influence of social context on the hedonic and relational dimensions of smartphone use. A high level of social influence reinforces hedonic value, but also store loyalty. Finally, since in-store smartphone use is public, demonstrating to others the ability to benefit from information and personalized offers can be considered a source of symbolic value (Arbore et al., 2014) whereby users are perceived as "smart shoppers" (de Kerviler et al., 2016b), but also as a motivation to remain loyal to the store.

In line with the above, we hypothesise as follows:

H4: The effect of in-store smartphone use on store value is stronger when the level of social influence is higher.

H4a: The effect of in-store smartphone use on utilitarian store value is stronger when the level of social influence is higher.

H4b: The effect of in-store smartphone use on hedonic store value is stronger when the level of social influence is higher.

H4c: The effect of in-store smartphone use on symbolic store value is stronger when the level of social influence is higher. 
Figure 1 presents the conceptual model and hypotheses.

[Insert Figure 1]

\section{Methodology}

\section{Context, sampling and data collection}

A quantitative research was conducted via a questionnaire administered through a market research company. The questionnaire comprised three main sections: 1) filter and general questions (motivation behind smartphone use, frequency of store visits, duration of relationship with store, familiarity with technology); 2) construct measurement; and 3) sociodemographic variables (e.g. gender, age, profession, income and education). Respondents were targeted via quota sampling based on age, gender, profession and geographical regions in France. A filter question ensured that they had all used their smartphone within stores when shopping over the previous six months. All participants were at least 18 years of age and fully or partially in charge of purchasing food products for their household. We decided to limit the survey to superstores to ensure homogeneity of store format and retail store type. We asked respondents for answers relating to the store/retail chain where they shopped most often, thus ensuring familiarity with the retailer.

Overall, 863 completed questionnaires were obtained after deleting those that were incomplete or contained errors. Respondents reported different motivations for smartphone use: comparing prices $(29 \%)$, information searches $(34 \%)$, other $(37 \%)$. Frequency of store visits varied: around once every six months (25\%), around once every three months $(19 \%)$, around once a month (20\%), and around once a week (36\%). We also found a high level of familiarity with technology: low (5.5\%), medium (45.8\%) and high (48.7\%). 
In terms of socio-demographic profiles, the sample was diverse. Most respondents were men (59\%). All age groups were represented: young (18-34: $17.2 \% ; 35-49: 35.7 \%$; 50-64: 34.2\%; and over 64: 12.9\%). Levels of education were generally high: high school or less (20\%), bachelor's level (50\%) and master's/PhD level (29\%). Monthly household incomes were well distributed: $\leq € 1,120(7.7 \%), € 1,121-2,000(19.8 \%), € 2,001-4,000(47.9 \%)$, and $>€ 4,000(24 \%)$. These figures are indicative of a balanced sample and roughly replicate the population segments that use digital tools in stores in France.

Table 1 presents the sample profiles.

[Insert Table 1 about here]

\section{Construct measures and operationalisation}

The survey instrument is based on a comprehensive review of the relevant literature. Because the scales come from different contexts, we used translation/back-translation methods with the help of fluent speakers. A questionnaire pretest ensured clear understanding of the items and instructions, indicating that it is sufficiently refined to avoid comprehension biases. Except customer smartphone use, all the variables use Likert scales $(1=$ "strongly disagree" to 7 = "strongly agree"), operationalised with well-established measurement scales.

Customer smartphone use was measured following Venkatesh et al. (2003). This measure relies on frequency of use and provides a good representation of usage behaviour. Specifically, we asked respondents to report frequency of smartphone use while shopping in the store they mostly frequent. Five options along with percentages of use were available: $1=$ For the first time; $2=$ Rarely $(<25 \%) ; 3=$ Moderately $(26-50 \%) ; 4=$ Often $(51-75 \%) ; 5=$ Very often $(>75 \%)$. Store value was measured using an adapted version of scales developed by Walsh et al. (2014) and Mimouni-Chaabane and Volle (2010). Three main dimensions were used: utilitarian value, hedonic value and symbolic value. This distinction is in line with 
the seminal work of Babin et al. (1994) on shopping value. To measure store loyalty, we used items from Yoo and Donthu (2001) and Zhang and Peterson (2004). These refer to the ability of the store to retain consumers in the present or future. To measure social influence, we relied on the scale developed by Venkatesh et al. (2003). This scale comprises different items related to social influence. We added a measure of technological sophistication to account for its effects as a control variable on the model. We used the Garnier and Macdonald's (2009) scale of technological sophistication. Finally, socio-demographic variables (age, gender, income, education) were also included in the questionnaire, measured with a categorisation scheme. Appendix 1 presents the measurement items.

\section{Data analysis and results}

\section{Measurement model assessment}

Exploratory factor analyses $(\mathrm{N}=862)$ with Varimax rotation in SPSS 18 helped confirm the first structure of each scale. The KMO values were greater than .70, the explained variance was greater than $50 \%$, and all item loadings were greater than .7. Furthermore, the Cronbach's alpha values were as follows: utilitarian store value $(\alpha=.91)$, hedonic store value $(\alpha=.96)$, symbolic store value $(\alpha=.89)$, store loyalty $(\alpha=.89)$, social influence $(\alpha=.89)$, and technological sophistication $(\alpha=.89)$. The exploratory stage therefore demonstrates sound scale properties.

A confirmatory factor analysis (maximum likelihood estimation) in AMOS 18 revealed the final structure of the measurement models $(\mathrm{N}=862)$, prior to structural model testing (Gerbing and Anderson, 1988). The overall measurement model indices indicate satisfactory or acceptable model fit $\left(\chi^{2}=912.21, \mathrm{df}=210, p=.000\right.$; root mean square error of approximation $[\mathrm{RMSEA}]=.062$; Goodness of Fit $[\mathrm{GFI}]=0.91$; Adjusted Goodness of Fit 
$[\mathrm{AGFI}]=0.88^{4} ;$ confirmatory fit index $[\mathrm{CFI}]=.96$; Tucker-Lewis index $[\mathrm{TLI}]=.95 ; \chi^{2} / \mathrm{df}=$ 4.34). The constructs' internal consistency was adequate; the composite reliability ( $\rho$ ) values were greater than the recommended cut-off (.7) overall and in each of the two sub-samples analysed. Table 2 reports item loadings (all significant at $p<.01$ ). Appendix 2 reveals satisfactory reliability $(\mathrm{CR}>.07)$ and the convergent validity of the constructs. The average variance extracted (AVE) values $\left(\rho_{\mathrm{vc}}\right)$ exceeded .5 (Fornell and Larcker, 1981). Because the AVE for each construct was also greater than the square of the inter-construct correlations, all constructs and dimensions fulfilled the requirements for discriminant validity (Fornell and Larcker, 1981), as documented in detail in Appendix 2.

\section{[Insert Table 2]}

The survey responses came from single key respondents in stores in France, thus requiring a check for potential common method bias (Podsakoff et al., 2003). First, the post hoc tests showed no evidence that a single factor accounted for all the covariance between the variables. Second, according to a marker variable technique based on the smallest correlation ${ }^{5}$ (Malhotra, Kim, and Patil, 2006), the differences between the original and corrected correlations were small and non-significant $(\Delta \mathrm{r}<.05)$. Thus, common method bias does not appear to influence the parameter estimates.

\footnotetext{
${ }^{4}$ AGFI being sensitive to sample size (Kline, 2010), we consider the value obtained acceptable given the exploratory nature of the research and sample size.

${ }^{5}$ The correlation between in-store smartphone use and hedonic value $(r=.14)$ served as the reference for the marker variable.
} 


\section{Structural model and hypotheses testing}

The hypothesised structural model (Model 1) shows a good fit with the data overall $\left(\chi^{2}=\right.$ $659.58, \mathrm{df}=110, \mathrm{p}=.000 ; \mathrm{RMSEA}=.076^{6} ; \mathrm{GFI}=0.91 ; \mathrm{AGFI}=0.88^{6} ; \mathrm{CFI}=.95 ; \mathrm{TLI}=.94 ;$ $\left.\chi^{2} / \mathrm{df}=5.99\right)$. The predictors explained substantial amounts of variance in the dependent variable (store loyalty) overall $\left(\mathrm{R}^{2}=.56\right)$. To ensure good focal model fit (Model 1), we assessed two alternative models: a direct model - Model 2 (i.e., no mediation, all factors directly affect loyalty), and a full mediation model - Model 3 (i.e., in-store smartphone use has no direct effect on store loyalty, and everything is mediated by the three value dimensions). A chi-square difference test with the direct Model 2 indicates that the focal model has a better fit $\left(\Delta \chi^{2}(\mathrm{df})=44.81(3), p<.01\right) \cdot{ }^{7}$ A comparison between the hypothesised model and the full mediation Model 3 further indicates the superiority of Model $1\left(\Delta \chi^{2}(\mathrm{df})=\right.$ $4.67(1), p<.1) .^{8}$

To test the direct effect of in-store smartphone use, we relied on a $t$-test and its associated $p$-value. The test for mediation effects used bootstrapping, which yields robust estimations (Cheung and Lau, 2008). MacKinnon, Lockwood and Williams (2004) examined the accuracy of confidence intervals for indirect effects and showed that the bias-corrected (BC) bootstrap method produces the most accurate confidence intervals. Furthermore, to obtain the significance of each specific indirect effect (not provided by AMOS), a Sobel test provides the mediation assessment. ${ }^{9}$

Table 3 summarises the results. In-store smartphone use positively but marginally affects store loyalty $(\gamma=.06, p<.05)$. Thus, $\mathrm{H} 1$ is confirmed. It has also an indirect influence

\footnotetext{
${ }^{6}$ The RMSEA value is correct, but close to the standard cutoff of 0.08 . AGFI is slightly less than 0.90 . These values might relate to the exploratory nature of studies on smartphone use, but also to the large sample size. In fact, SEM fit indices are generally sensitive to sample size (Kline, 2010).

${ }^{7}$ Fit indices for Model 2: $\chi^{2}=701.38, \mathrm{df}=113, p=.000 ; \mathrm{RMSEA}=.078 ; \mathrm{CFI}=.95 ; \mathrm{TLI}=.94 ; \chi^{2} / \mathrm{df}=6.20$.

${ }^{8}$ Fit indices for Model 3: $\chi^{2}=661.24, \mathrm{df}=111, p=.000 ; \mathrm{RMSEA}=.076 ; \mathrm{CFI}=.95 ; \mathrm{TLI}=.94 ; \chi^{2} / \mathrm{df}=5.95$.

${ }^{9}$ Preacher online tool: http://quantpsy.org/sobel/sobel.htm.
} 
on store loyalty through the three specific value dimensions. The indirect bootstrap coefficient obtained $(\gamma=.14)$ is significant at $p<.01$. Thus, the mediation effect of store value is demonstrated and $\mathrm{H} 2$ confirmed. We then analyse each specific mediation effect. In-store smartphone use positively affects utilitarian store value $(\gamma=.23, p<.01)$. However, utilitarian store value has no influence on store loyalty $(\gamma=.06, p>.05)$. The product of these two effects is non-significant $(p>.05)$. Therefore, H2.1 is rejected. In-store smartphone use significantly influences hedonic store value $(\gamma=.14, p<.01)$, which in turn affects store loyalty $(\gamma=.33, p<.01)$. The product of these two effects is significant $(\gamma=.046, p<.01)$, confirming H2.2. In-store smartphone use also has a significant effect on symbolic store value $(\gamma=.20, p<.01)$, which affects store loyalty $(\gamma=.40, p<.01)$. The product of these two effects is significant $(\gamma=.084, p<.01)$, confirming H2.3.

\section{[Insert Table 3]}

To assess the moderation effect of the level of social influence, we calculated the median value (4) and split the sample into two segments excluding the median value. That led to two groups: low social influence customers $(\mathrm{N}=290)$ and high social influence customers $(\mathrm{N}=219)$. The two groups differ in terms of motivation for smartphone use during shopping trips. The low social influence group reports price comparison (21\%) and information searches $(33 \%)$, while the respective values for the high social influence group are $38 \%$ and $40 \%$. In terms of socio-demographic profiles (gender, age, income, education), the two groups have similar distribution, making the comparison more appropriate.

Next, we relied on multiple group analyses in AMOS. A comparison of the focal (unconstrained) model with one in which the structural parameters were constrained to equality reveals, according to a $\Delta \chi$ test, that the two models differ significantly overall: $\Delta \chi=$ 37.42, df $=18, p<.05$. In other words, social influence significantly moderates the 
relationships investigated in the research model. Each individual path of interest was then analysed to determine whether or not it is moderated and reveal the significance of the difference between the groups with low and high level of social influence.

Table 4 presents the findings. It indicates that the effect of in-store smartphone use on store loyalty is weaker for higher than lower social influence $\left(\gamma_{1}=.13 ; \gamma_{2}=.02, p<.01\right)$. This reveals a significant moderation effect as anticipated, supporting $\mathrm{H} 3$. The effect of utilitarian store value on store loyalty does not differ between the lower and higher social influence groups $\left(\gamma_{1}=.20 ; \gamma_{2}=.28, p>.05\right)$. Thus, $\mathrm{H} 4 \mathrm{a}$ is rejected. The effect of hedonic store value on store loyalty is stronger for higher social influence $\left(\gamma_{1}=.08 ; \gamma_{2}=.25, p<.01\right)$, confirming H4b. Finally, we uncover a significant difference between higher and lower social influence groups on the relationship between symbolic store value and store loyalty $\left(\gamma_{1}=.08 ; \gamma_{1}=.33, p\right.$ $<.01$ ), supporting H4c.

[Insert Table 4]

\section{Robustness check and controls}

To confirm the robustness of the results, a final check incrementally added consumer characteristics (age, gender, income, education) and technological sophistication as control variables. As covariates in the model, education $(\gamma=-.10, p<.05)$ marginally affects store loyalty while gender $(\gamma=-.01, p>.05)$, age $(\gamma=.05, p>.05)$, income $(\gamma=.00, p>.05)$ and education $(\gamma=-.08, p>.05)$ do not. Age $(\gamma=-.84, p<.01)$, gender (man/woman) $(\gamma=-.46, p$ $<.01)$ and income $(\gamma=-.02, p>.05)$ significantly affect in-store smartphone use, while education does not. However, adding these covariates significantly worsens model fit $\left(\chi^{2}=\right.$ $\left.1057.69, \mathrm{df}=180, p=.000 ; \mathrm{RMSEA}=.075 ; \mathrm{CFI}=.93 ; \mathrm{TLI}=.92 ; \chi^{2} / \mathrm{df}=5.87\right)$ and does not 
change the substantive findings. Therefore, it is not appropriate to include them in the focal model.

We also analysed the effects of technological sophistication on the research model. Results show that it only marginally affects store loyalty $(\gamma=.06, p<.05)$, but more significantly affects in-store smartphone use $(\gamma=.06, p<.05)$. The integration of this covariate significantly worsens model fit $\left(\chi^{2}=878.51\right.$, df $=160, p=.000 ; \operatorname{RMSEA}=.072$; $\left.\mathrm{CFI}=.94 ; \mathrm{TLI}=.94 ; \chi^{2} / \mathrm{df}=5.49\right)$ and does not change the substantive findings.

\section{Discussion and conclusions}

\section{Theoretical contributions}

This study investigates how customers' in-store smartphone use influences store loyalty through value dimensions and depending on social influence level. It complements the recent study of Bellini and Aiolfi (2020) that shows that mobile devices could be used out-of-store, as a tool for shopping preparation, and in-store as a tool for self-regulation. This article brings two main broad theoretical contributions to both marketing and information systems research. First, our results show that in-store smartphone use only marginally affects customer loyalty to the store directly. However, it does affect it indirectly through the mediation of two specific value dimensions: hedonic and symbolic value in contrast to utilitarian value. Thus, instead of focusing on price and other utilitarian features (Ipek et al., 2016), this research underlines the central role of non-utilitarian value in line with Melumad and Pham (2020). In fact, while the convenience of mobile devices for purchase behaviour has been now explored (Bellini and Aiolfi, 2017, 2020; de Kerviler et al., 2016a; Grewal et al., 2018), the effects of smartphone use on both hedonic and symbolic values have not been clarified. This research establishes the important role of hedonic value in the way customers use technology. It specifically demonstrates that hedonic store value mediates the effect of in-store smartphone use on store 
loyalty. Furthermore, the role of symbolic value has been neglected in prior marketing studies on the use of new technology. This article underscores the critical role of symbolic store value as a mediator in the relationship between in-store smartphone use and store loyalty, thus building on the existing research on both the adoption of new technology and customer loyalty in an omni-channel retail context (Inman and Nikolova, 2017; Grewal et al., 2018; Verhoef et al., 2017).

Second, considering the centrality of social influence in our digitalized economies (Argo and Dahl, 2020; Sridhar and Srinivasan, 2012), this research reveals its moderation effects on the specific relationships studied. Our findings make two primary contributions to the research on social influence in response to the recent call from Argo and Dahl (2020) for further research on this topic. First, our results reveal that the effect of in-store smartphone use on store loyalty is stronger when social influence is low, and second, that the effect of hedonic and symbolic store value on store loyalty is stronger when social influence is high. These results are supported by social influence theory (Kelman, 1958). Customers use smartphones to find relevant information or alternative offers and prices from the competition (de Kerviler et al., 2016b, Kirova and Thanh, 2019). Thus, loyalty is expected to be lower because of the quick access to competitive offers made available via smartphones. In contrast, combining positive hedonic/symbolic values and higher (positive) social influence strengthens store loyalty. These findings extend prior studies on social influence, store value and loyalty. The literature tells us that social influence facilitates the adoption and diffusion of technologies (Arbore et al., 2014; Venkatesh et al., 2003, 2012) through the reduction of perceived risk and information transfer among individuals (Van den Bulte and Lilien, 2001). This research extends prior studies (Giovanis et al., 2018; Osei-Frimpong, 2019) and enriches our knowledge of the specific effects of social influence. Indeed, it shows how the latter 
decreases or increases customer loyalty when combined with in-store smartphone use or store value dimensions (hedonic and symbolic).

\section{Practical implications}

This research indicates to retail managers how to position stores on specific value dimensions to improve loyalty. We also provide specific guidance to retailers as to how they should monitor and use social influence appropriately and consequently mitigate showrooming behaviour for instance.

First, consumers now expect to be able to use their mobile as and whenever they want, and so it is crucial to provide them with high-performance connectivity and free Wi-Fi anywhere in the store. Specifically, stores should help consumers gain easy access to product information, shopping list capabilities, and personalized recommendations via their smartphone. One main focus here is proactively providing consumers with a rich and seamless experience in stores. This recommendation is especially critical for young consumers, who seek high-quality connections in their daily life. Retailers could imagine offering different services (e.g. personalized offers or gaming services) to help them optimize their time (e.g. waiting time) during shopping trips.

Second, consumers who use the retailer's app while in store and those who answer other consumers' questions in real time could be rewarded by points through a loyalty program. Existing loyalty programs should be quickly updated. In fact, some loyalty programs do not yet allow consumers to use the same program online and offline. However, in an omnichannel context, consumers should benefit from cross-channel rewards. With the internet, rewards programs have become even more far-reaching. Retailers should ensure that loyalty membership schemes enable consumers to check their "progress" (online/offline) at any time. The internet also allows retailers to enrich their loyalty programs and attract/keep consumers 
both online and offline even more effectively. For instance, exclusive offers and a gamified system can make these programs highly engaging. Specific features (e.g. mobile push notifications) can also modernize retail advertising and complement physical stores. Thanks to mobile apps, retailers can also reward consumers' pro-social behaviors in relation to the store (recycling, carbon footprint, etc.).

Third, it is paramount to differentiate between the marketing approach of consumers with low versus high level of social influence. For the former, retailers should favor utilitarian value creation by developing mobile apps that offer task-related functions while shopping, such as providing customers with helpful information (e.g. nutritional values of product, store location, etc.). While for the latter, retailers can push personalised in-store offers and promotions via their mobile app to reinforce the self-esteem of these consumers and their image as smart shoppers. This will foster both hedonic and symbolic values.

Finally, in order to prevent negative social influence from competitors or dissatisfied consumers on their customers while in store, retailers are advised to develop "controlled" social influence through their own private mobile app. They should provide a platform/forum for their customers to favor interactivity (information exchanges, answers to questions asked in store, etc.) and a sense of belonging as members of the store/retailer's community. Siregar and Kent (2019) have recently underlined the critical role of interactive information and interaction moments. By accessing this mobile app/platform, all actors (consumers and personnel, both in and out of the store) can interact through the real-time exchange of information throughout the store visit, increasing store value and hence store loyalty. This social influence via in-store mobile use can complement the physical presence and availability of sales personnel. Such an app could also help to counterbalance the influence of social media and external price comparisons. 


\section{Limitations and future research}

Despite its theoretical and managerial contributions, this paper has a few limitations that point to several research avenues. First, it was carried out in one country (France). A cross-cultural comparison would be interesting, as retailers operate worldwide and cultural differences could be significant both in terms of in-store smartphone use and social influence. It would also be useful to study the differences between the consequences of low versus high level of social influence for the relationships studied according to the store type - convenience versus experiential. Moreover, a multi-method study with complementary methodologies such as field experiments could enhance our understanding of the role of social influence. Furthermore, as suggested by Argo and Dahl (2020), it is crucial to understand the complexity of multiple sources of social influence on the customer. It would be particularly interesting to study the respective impact of social influence of retail personnel on store value and store loyalty. Finally, a longitudinal approach could provide further insights into the increasingly pervasive (BRP report 2019) in-store use of smartphones and other wearables (Apple watch, etc.). 


\section{References}

Arbore, A., Graziani, R. and Venturini, S. (2014), "Understanding Personal Mobile Technologies: Decomposing and De-Averaging the Value of a Smartphone”, Journal of Information Systems, Vol. 28 No.1, pp. 167-185.

Argo, J.J., Dahl, D.W and Manchanda, R.V. (2005), "The Influence of a Mere Social Presence in a Retail Context," Journal of Consumer Research, Vol. 32 No.2, pp. $207-$ 212.

Argo, J.J., and Dahl, D.W (2020), "Social influence in the retail context: A contemporary review of the literature", Journal of Retailing, Vol. $96 \mathrm{~N}^{\circ} 1$, pp. 25-39.

Audrin, B. (2020), "Implementing self-service technologies: not without competition!" International Journal of Retail \& Distribution Management, Vol. 48 No. 2, pp. 169185.

Babin, B. J., Darden, W.R. and Griffin, M. (1994), "Work and/or fun: Measuring hedonic and utilitarian shopping value", Journal of Consumer Research, Vol. 20 No. 4, pp. 644-556.

Bellini, S. and Aiolfi, S. (2017), "The impact of mobile device use on shopper behavior in store: an empirical research on grocery retailing”, International Business Research, Vol. 10 No. 4, pp. 58-68.

Bellini, S. and Aiolfi, S. (2020), "Impulse buying behavior: the mobile revolution", International Journal of Retail \& Distribution Management, Vol. 48 No. 1, pp. 1-17.

Bellini, S., Cardinali, M. G. and Aiolfi, S. (2018), "Using mobile device in-store: which implications for retailers?, International Journal of System Modeling \& Simulation, Vol. 3 No. 1, pp. 12-17.

Bloemer, J. and de Ruyter, K. (1998), "On the relationship between store image, store satisfaction and store loyalty", European Journal of Marketing, Vol. 32 No. 5/6, pp. 499-513,

Chebat, J-C., Haj-Salem, N. and Oliveira, S. (2014), "Why shopping pals make malls different", Journal of Retailing and Consumer Services, Vol. 21 No. 2, pp. 77-85.

Cheung, G.W. and Lau, R.S. (2008), “Testing mediation and suppression effects of latent variables: Bootstrapping with structural equation models", Organizational Research Methods, Vol. 11 No. 2, pp. 296-325.

Daunt, K.L. and Harris, L.C. (2017), "Consumer showrooming: Value co-destruction", Journal of Retailing \& Consumer Services, Vol. 38, pp. 166-176. 
Davis, L. and Hodges, N. (2012), "Consumer shopping value: An investigation of shopping trip value, in-store shopping value and retail format", Journal of Retailing and Consumer Services, Vol. 19, pp. 229-239.

de Haan, E., Kannan, P. K., Verhoef, P. C. and Wiesel, T. (2018), "Device Switching in Online Purchasing: Examining the Strategic Contingencies”, Journal of Marketing, Vol. 82 No. 5, pp. 1-19.

de Kerviler, G., Demoulin, N. and Zidda, P. (2016a), “Adoption of in-store mobile payment: are perceived risk and convenience the only drivers?", Journal of Retailing and Consumer Services, Vol. 31, pp. 334-344.

de Kerviler, G., Demoulin N. and Zidda, P. (2016b, May), "Why shoppers use their Smartphone for an in-store purchase?", Proceedings of the French Marketing Association Conference, Lyon, France.

Diallo, M. F., Coutelle-Brillet, P., Rivière, A. and Zielke, S. (2015), "How do price perception of different brand types affect shopping value and store loyalty?", Psychology and Marketing, Vol. 32 No. 12, pp. 1133-1147.

Falk, T., Kunz, W H., Schepers, J. J. L. and Mrozek, A. J. (2016), "How mobile payment influences the overall store price image", Journal of Business Research, Vol. 69 No. 7 , pp. 2417-2423.

Fornell, C. and Larcker, D.F. (1981), "Evaluating structural equation models with unobservable variables and measurement error", Journal of Marketing Research, Vol. 18 No. 1 , pp. 39-50.

Francioni, B., Savelli, E., Cioppi, M. (2018). «Store satisfaction and store loyalty: the moderating role of store atmosphere", Journal of Retailing and Consumer Services, Vol. 43, pp. 333-341.

Garnier, M. and Macdonald, E. (2009), "The savvy French consumer: a cross-cultural replication", Journal of Marketing Management, Vol. 25 No. 9-10, pp. 965-986.

Gerbing, D.W. and Anderson, J.C. (1988), “An updated paradigm for scale development incorporating unidimensionality and its assessment", Journal of Marketing Research, Vol. 25 No. 2, pp. 186-192.

Giovanis, A., Assimakopoulos, C., and Sarmaniotis, C. (2018), "Adoption of mobile selfservice retail banking technologies", International Journal of Retail \& Distribution Management, Vol. 47 No. 9, pp. 894-914. 
Graciola, A.P., Toni, D., Milan G.S., and Eberle, L. (2020), "Mediated-moderated effects: High and low store image, brand awareness, perceived value from mini and supermarkets retail stores", Journal of Retailing and Consumer Services, Vol. 55, 16 p.

Grewal, D., Bart, Y., Spann, M. and Zubcsek, P. P. (2016), "Mobile advertising: A framework and Research agenda", Journal of Interactive Marketing, Vol. 34 (May), pp. 3-14.

Grewal, D., Ahlbom, C.-P., Beitelspacher, L., Noble, S. M. and Nordfält, J. (2018), "In-store mobile phone use and customer shopping behavior: Evidence from the field", Journal of Marketing, Vol. 82 No. 4, pp. 102-126.

Grewal, D., Noble, S.M., Roggeveen A.L., and Nordfält, J. (2020), “The Future of In-Store Technology”, Journal of the Academy of Marketing Science, Vol. 48 No.1, pp. 96-113.

Haenlein, M. (2013), "Social interactions in customer churn decisions: The impact of relationship directionality", International Journal of Research in Marketing, Vol. 30 No. 3, pp. 236-248

Hu, X., Chen, X. and Davidson, R. (2019) "Social Support, Source Credibility, Social Influence, and Impulsive Purchase Behavior in Social Commerce", International Journal of Electronic Commerce, Vol. 23 No.3, pp. 297-327.

Inman, J.J. and Nikolova, H. (2017), "Shopper-facing retail technology: A retailer adoption decision framework incorporating shopper attitudes and privacy concerns", Journal of Retailing, Vol. 93 No.1, pp. 7-28.

İpek, İ., Aşkın, N. and İlter, B. (2016), "Private label usage and store loyalty: The moderating impact of shopping value", Journal of Retailing and Consumer Services, Vol. 31, pp. $72-79$.

Jackson, V., Stoel, L., and Brantley, A. (2011), "Mall attributes and shopping value: Differences by gender and generational cohort", Journal of Retailing and Consumer Services, Vol. 18, pp. 1-9.

Jones, M.A., Reynolds, K.E. and Arnold, M.J. (2006), "Hedonics and utilitarian value: investigating differential effects on retail outcomes", Journal of Business Research, Vol. 59 No. 9, pp. 974-981.

Jung, Y. (2014), "What a Smartphone is to me: understanding user values in using Smartphones”, Information Systems Journal, Vol. 24 No. 4, pp. 299-321.

Kamran-Disfani, O., Mantrala, M.K., Izquierdo-Yusta, A. and Martínez-Ruiz, M.P. (2017), "The impact of retail store format on the satisfaction-loyalty link - an empirical investigation", Journal of Business Research, Vol. 77, pp. 14-22. 
Kelman, H. C. (1958), "Compliance, Identification, and Internalization: Three Processes of Attitude Change?", Journal of Conflict Resolution, Vol. 2, pp. 51-60.

Kim, W.G., Lee, C., and Hiemstra, S.J. (2004), "Effects of an online virtual community on customer loyalty and travel product purchases”, Tourism Management, Vol. 25 No. 3, pp. 343-355.

Kim, Y.-K., Lee, M.-Y., and Park, S. (2014), "Shopping value orientation: Conceptualization and measurement", Journal of Business Research, Vol. 67, pp. 2884-2890.

Kirova, V. and Thanh, T. V. (2019), "Smartphone use during the leisure theme park visit experience: The role of contextual factors", Information \& Management, Vol. 56 No. 5 , pp. 742-753.

Kline, R.B. (2010), Principles and practice of structural equation modeling, Third Edition, Guilford Press: New York.

Konuk, F. A. (2018) "The role of store image, perceived quality, trust and perceived value in predicting consumers' purchase intentions towards organic private label food", Journal of Retailing \& Consumer Services, Vol. 43, pp. 304-310

Kowatsch, T. and Maass, W. (2010), "In-store consumer behavior: How mobile recommendation agents influence usage intentions, product purchases, and store preferences", Computers in Human Behavior, Vol. 26 No. 4, pp. 697-704.

Lemon, K. N. and Verhoef, P. C. (2016), "Understanding customer experience throughout the customer journey, Journal of marketing, Vol. 80 No. 6, pp. 69-96.

Levy, S.J. (1959), “Symbols for sale”, Harvard Business Review, Vol. 37 No.4, pp. 117-124.

Lombart, C. and Louis, D. (2012), "Consumer satisfaction and loyalty: Two main consequences of retailer personality", Journal of Retailing \& Consumer Services, Vol. 19 No.6, pp. 644-652.

MacKinnon, D., Lockwood, C. and Williams, J. (2004), “Confidence limits for the indirect effect: distribution of the product and resampling methods", Multivariate Behavioral Research, Vol. 39 No. 1, pp. 99-128.

Malhotra, N.K., Kim, S.S. and Patil, A. (2006), "Common method variance in is research: A comparison of alternative approaches and a reanalysis of past research", Management Science, Vol. 52 No. 12, pp.1865-1883.

McLean, G., Al-Nabhani, K. and Wilson, A. (2018), "Developing a Mobile Applications Customer Experience Model (MACE) - Implications for retailers", Journal of Business Research, Vol. 85, pp. 325-336. 
Melumad, S. and Pham M. T. (2020), "The smartphone as a pacifying technology”, Journal of Consumer Research, Vol. 47 No. 2, pp. 237-255

Mimouni-Chaabane, A. and Volle, P. (2010), "Perceived benefits of loyalty programs: Scale development and implications for relational strategies", Journal of Business Research, Vol. 63 No.1, pp. 32-37.

Nitzan, I. and Libai, B. (2011), "Social effects on customer retention", Journal of Marketing, Vol. 75 No. 6, pp. 24-38.

Nunes, J. C., Drèze, X and Han, Y. J. (2011), "Conspicuous consumption in a recession: Toning it down or turning it up?", Journal of Consumer Psychology, Vol. 21 No. 2, pp. 199-205.

Osei-Frimpong, K. (2019), "Understanding consumer motivations in online social brand engagement participation", International Journal of Retail \& Distribution Management, Vol. 47 No. 5, pp. 511-529.

O'Cass, A. and Carlson, J. (2012), “An empirical assessment of consumers' evaluations of web site service quality: conceptualizing and testing a formative model", Journal of Services Marketing, Vol. 26 No. 6, pp. 419-434.

Papagiannidis S., Pantano E., See-To E., Dennis C. and Bourlakis M. (2017), “To immerse or not? Experimenting with two virtual retail environments", Information Technology \& People, Vol. 30 No. 1, pp. 163-188.

Podsakoff, P.M., MacKenzie, S.B., Lee, J.-Y. and Podsakoff, N.P. (2003), "Common methods biases in behavioral research: A critical review of the literature and recommended remedies", Journal of Applied Psychology, Vol. 88 (October), pp. 879903.

Purani, K., Kumar, D.S. and Sahadev, S. (2019), "e-Loyalty among millennials: Personal characteristics and social influence", Journal of Retailing and Consumers Services, Vol. 48, pp. 215-223.

Rippé, C., Weisfeld-Spolter, S., Yurova, Y., Dubinsky, J. A. and Hale, D. (2017), "Under the sway of a mobile device during an in-store shopping experience", Psychology \& Marketing, Vol. 34, pp. 733-752.

Rokonuzzaman, M., Harun, A., Al-Emran, M, and Prybutok, V.R. (2020), “An investigation into the link between product involvement and store loyalty: The roles of shopping value goals and information search as the mediating factors “, Journal of Retailing and Consumers Services, Vol. 52. 
Sciandra, M.R. and J. Jeffrey Inman, J.J. (2015), "Smart Phones, Bad Calls? In-Store Mobile Technology Use and Consumer Purchase Behavior", in NA - Advances in Consumer Research eds. Kristin Diehl and Carolyn Yoon, Duluth, MN : Association for Consumer Research, Vol. 43, pp.117-121.

Singh, R. (2019), "Why do online grocery shoppers switch or stay? An exploratory analysis of consumers' response to online grocery shopping experience", International Journal of Retail \& Distribution Management, Vol. 47 No. 12, pp. 1300-1317.

Siregar, Y. and Kent, A. (2019), "Consumer experience of interactive technology in fashion stores”, International Journal of Retail \& Distribution Management, Vol. 47 No. 12, pp. 1318-1335.

Sridhar, S. and Srinivasan, R. (2012), "Social influence and online product ratings", Journal of Marketing, Vol. 76 No. 5, pp. 70-88.

Van den Bulte, C. and Lilien G. L. (2001), "Medical innovation revisited: Social contagion versus marketing effort", American Journal of Sociology, Vol. 106 No. 5, pp.14091435 .

van Heerde, H. J., Dinner, I. M. and Neslin, S. A. (2019), "Engaging the unengaged customer: The value of a retailer mobile app", International Journal of Research in Marketing, Vol. 36 No. 3, pp. 420-438.

Venkatesh, V., Morris, M. G., Davis, G.B and Davis F. D. (2003), "User acceptance of information technology: toward a unified view", MIS Quaterly, Vol. 27 No. 3, pp. 425 478.

Venkatesh, V., Thong, J. Y. L., and Xu, X. (2012), "Consumer acceptance and use of information technology: Extending the unified theory of acceptance and use of technology”, MIS Quarterly, Vol. 36 No.1, pp. 157-178.

Verhoef, P. C., Stephen, A. T., Kannan, P. K., Luo, X., Vibhanshu, A., Andrews, M., et al. (2017), "Consumer connectivity in a Complex, Technology-Enabled, and mobileoriented world with smart products", Journal of Interactive Marketing, Vol. 40 No. 1-8.

Walsh, G., Shiu, E. and Hassan, L. M. (2014), "Replicating, validating, and reducing the length of the consumer perceived value scale", Journal of Business Research, Vol. 67 No. 3, pp. 260-267.

Yoo, B. and Donthu, N. (2001), "Developing and validating a multidimensional consumerbased brand equity scale", Journal of Business Research, Vol. 52 No. 1, pp. 1-14. 
Zhang, X., Li, S., Burke R. R. and Leykin, A. (2014), “An examination of social influence on shopper behavior using video tracking data", Journal of Marketing, Vol. 78 No. 5, pp. 24-41.

Zhang Z. and Peterson R.T. (2004), "Customer perceived value, satisfaction, and loyalty: The role of switching costs", Psychology and Marketing, Vol. 21 No. 10, pp. 799-822. 


\section{Appendices}

Appendix 1. Measurement items and variable sources

\begin{tabular}{|c|c|c|}
\hline Constructs & Measurement items & Sources \\
\hline $\begin{array}{l}\text { 1. Customers' in- } \\
\text { store smartphone } \\
\text { use }\end{array}$ & $\begin{array}{l}\text { I use my smartphone while shopping in store } \mathrm{Y} \\
\qquad[1=\text { First time to } 5=\text { Very often }]\end{array}$ & $\begin{array}{l}\text { Adapted from } \\
\text { Venkatesh et al. } \\
(2003)\end{array}$ \\
\hline $\begin{array}{l}\text { 2. Utilitarian store } \\
\text { value }\end{array}$ & $\begin{array}{l}\text { Utill. Store } Y \text { allows me to shop at a lower } \\
\text { financial cost } \\
\text { Util2. Store } Y \text { allows me to spend less } \\
\text { Util3. Store } Y \text { helps me to save money } \\
\text { Util4. I discover new products at store } Y\end{array}$ & $\begin{array}{l}\text { Adapted from } \\
\text { Walsh et al. (2014) } \\
\text { and Mimouni- } \\
\text { Chaabane and } \\
\text { Volle (2010). }\end{array}$ \\
\hline $\begin{array}{l}\text { 3. Hedonic store } \\
\text { value }\end{array}$ & $\begin{array}{l}\text { Hed1. Store Y is entertaining } \\
\text { Hed2. Store Y is enjoyable } \\
\text { Hed3. Store Y makes me feel good about myself }\end{array}$ & $\begin{array}{l}\text { Adapted from } \\
\text { Walsh et al. (2014) } \\
\text { and Mimouni- } \\
\text { Chaabane and } \\
\text { Volle (2010). }\end{array}$ \\
\hline $\begin{array}{l}\text { 4. Symbolic store } \\
\text { value }\end{array}$ & $\begin{array}{l}\text { Symb1. Store Y takes better care of me } \\
\text { Symb2. Store Y treats me better than other } \\
\text { customers } \\
\text { Symb3. Store Y treats me with more respect } \\
\text { Symb4. Store Y allows me to belong to a } \\
\text { community of people who share the same values } \\
\text { Symb5. Store Y shares the same values than me }\end{array}$ & $\begin{array}{l}\text { Adapted from } \\
\text { Walsh et al. (2014) } \\
\text { and Mimouni- } \\
\text { Chaabane and } \\
\text { Volle (2010). }\end{array}$ \\
\hline 5. Store loyalty & $\begin{array}{l}\text { Loy1. I consider myself to be loyal to store Y } \\
\text { Loy2. Store Y would be my first choice } \\
\text { Loy3. I will not buy elsewhere if store Y is open } \\
\text { Loy4. I intend to continue to shop at store Y }\end{array}$ & $\begin{array}{l}\text { Adapted from Yoo } \\
\text { and Donthu (2001) } \\
\text { and Zhang and } \\
\text { Peterson (2004). }\end{array}$ \\
\hline 6. Social influence & $\begin{array}{l}\text { Soc1. People who are important to me think that } \\
\text { I should use innovative new technologies when } \\
\text { shopping }\end{array}$ & $\begin{array}{l}\text { Adapted from } \\
\text { Venkatesh et al. } \\
(2003)\end{array}$ \\
\hline
\end{tabular}




\begin{tabular}{|c|c|c|}
\hline & $\begin{array}{l}\text { Soc2. People who influence my behaviour think } \\
\text { that I should use innovative new technologies } \\
\text { when shopping } \\
\text { Soc3. People whose opinions I value suggest that } \\
\text { I use innovative new technologies when } \\
\text { shopping }\end{array}$ & \\
\hline $\begin{array}{l}\text { 7. Technological } \\
\text { sophistication }\end{array}$ & $\begin{array}{l}\text { Sophis1. Other people come to me for advice on } \\
\text { new technologies } \\
\text { Sophis2. In general, I am first among my circle } \\
\text { of friends to acquire new technology when it } \\
\text { appears } \\
\text { Sophis3. I can usually figure out new high-tech } \\
\text { products and services without help from others }\end{array}$ & $\begin{array}{l}\text { Garnier and } \\
\text { Macdonald (2009) }\end{array}$ \\
\hline
\end{tabular}


Appendix 2. Means, correlation matrix, and discriminant validity assessment

\begin{tabular}{|c|c|c|c|c|c|c|c|c|c|c|c|}
\hline \multirow[t]{2}{*}{ Constructs } & \multirow[t]{2}{*}{ Means } & \multirow[t]{2}{*}{ SD } & \multirow[t]{2}{*}{$\mathrm{CR}$} & \multirow[t]{2}{*}{ AVE } & \multicolumn{7}{|c|}{ Correlations } \\
\hline & & & & & 1 & 2 & 3 & 4 & 5 & 6 & 7 \\
\hline $\begin{array}{l}\text { 1. Customers' } \\
\text { in-store } \\
\text { smartphone } \\
\text { use }\end{array}$ & 3.22 & 2.02 & --- & --- & 1 & & & & & & \\
\hline $\begin{array}{l}\text { 2. Utilitarian } \\
\text { store value }\end{array}$ & 4.78 & 1.20 & .91 & .73 & 0.23 & 1 & & & & & \\
\hline $\begin{array}{l}\text { 3. Hedonic } \\
\text { store value }\end{array}$ & 4.09 & 1.33 & .96 & .89 & 0.14 & 0.54 & 1 & & & & \\
\hline $\begin{array}{l}\text { 4. Symbolic } \\
\text { store value }\end{array}$ & 3.92 & 1.13 & .92 & .71 & 0.20 & 0.60 & 0.70 & 1 & & & \\
\hline $\begin{array}{ll}5 . & \text { Store } \\
\text { loyalty } & \end{array}$ & 4.51 & 1.18 & .89 & .68 & 0.20 & 0.51 & 0.67 & 0.70 & 1 & & \\
\hline $\begin{array}{l}6 . \quad \text { Social } \\
\text { influence }\end{array}$ & 3.67 & 1.31 & .96 & .90 & 0.18 & 0.39 & 0.39 & 0.55 & 0.48 & 1 & \\
\hline $\begin{array}{l}7 . \\
\text { Technological } \\
\text { sophistication }\end{array}$ & 3.99 & 1.31 & .83 & .62 & 0.38 & 0.32 & 0.27 & 0.43 & 0.35 & 0.42 & 1 \\
\hline
\end{tabular}

Notes: $\mathrm{SD}=$ Standard deviation. $\mathrm{CR}=$ Composite reliability. AVE $=$ Average Variance Extracted. All correlations are significant at $p<.01$. The variable in-store smartphone use does not report AVE and CR values, because it is measured with a unique single indicator. For construct discriminant validity, the average variance extracted (AVE) values, must be greater than the squared correlations between constructs, which was the case for all constructs. 